\title{
The Russian Bear: Russian Strategic Culture and What it Implies for the West
}

\author{
Norbert Eitelhuber *
}

\begin{abstract}
This essay identifies the nature of Russia's strategic culture: it is its propensity to use force to achieve strategic objectives. It argues that Western policymakers have consistently misperceived the reasons for Russian foreign policy behavior, as they fail to take into account the enduring nature of Russia's strategic culture. This article claims that Russia has a strategic culture that is fairly stable, although significant changes occurred after the breakup of the Soviet Union. Most importantly, Russia's imperial ambitions vanished, along with the desire to spread an ideology. The role of military strength as a source of power declined, while the prominence of economic power increased. In the post-Cold War era, Russia has aimed at restoring its status within a great power order, improving the standard of living for its people, and developing (or revising) its national identity. At the same time, the strategic culture that prevails in Moscow makes Russia particularly sensitive to actions taken by the West. The article concludes by examining opportunities for accommodation and constructive engagement with Russia. To attenuate the tensions that currently exist, the West should react assertively but moderately to rhetorical saber rattling and other provocations, and engage in constructive cooperation on both contemporary security threats and economic issues, including pursuing close cooperation to mitigate the effects of the international financial crisis on Russia. In the near term, the West should focus on working with Russia to develop a new concept for long-term security and stability in Eurasia. Future research should thus focus on forward-looking networked diplomacy approaches that may be suited to overcome a Cold War mindset oriented toward bloc confrontation.
\end{abstract}

\section{Introduction}

Russia's military incursion into Georgia in August 2008 took many experts by surprise. In its wake, policymakers and scholars began to speculate about Russia's true motives. The Georgian president, Mikheil Saakashvili, stoked fears of a return of an imperialistic Russia that would "rebuild its empire, seize greater control of Europe's energy supplies and punish those who believed democracy could flourish." He also asked, "If Moscow can oust Georgia's democratically elected government, it can then intimidate other democratic European governments. Where will this end?"1 Some pundits already see Russia's Georgia strategy being replicated in the Ukraine, and hear echoes of the

Lieutenant Colonel GS Norbert Eitelhuber is currently serving as a Lecturer for Security Policy at the Bundeswehr Command and Staff College. After working as Research Associate for the German Institute for International and Security Affairs (SWP), he was a Consultant for the Federal Ministry of Defense (BMVg) and the Federal Ministry for Economic Cooperation and Development (BMZ). The views presented here are his, and do not represent official positions of the German government.

1 Mikheil Saakashvili, "Moscow's Plan Is to Redraw the Map of Europe," Financial Times (27 August 2008); available at www.ft.com/cms/s/0/fa0035f0-7459-11dd-bc91-0000779fd18c. html?nclick_check=1. 
Soviet Union's invasions of Hungary in 1956 and Czechoslovakia in 1968. Other experts point out that "it is more likely that Russia's strategic aims are modest, largely confined to its own neighborhood, and typical for a major power."2 According to this more sanguine view, Moscow's decision to send troops into Georgia is rather seen as a reaction to the policies that the United States and NATO have pursued in the post-Soviet space.

The policy implications that would proceed from these two points of view are entirely different. In the first case, the liberal democracies in the Euro-Atlantic sphere with market economies - which will be collectively referred to in this article as "the West"-would have to repel further Russian aggression with all means possible, and would be forced to band together against a resurgent Russia. In the second case, cooperation with Russia on the international stage to solve global problems would probably be the more constructive approach; this might even go as far as accepting that Russia has privileged interests in the region of the Commonwealth of Independent States (CIS).

This essay will examine these different perceptions scientifically by drawing on the concept of strategic culture. This concept may provide an explanatory framework for what can often seem to be irrational Russian foreign and security policy decisions. It may thus serve as a tool for policymakers to help define a Western policy towards Russia that can lead to cooperation instead of confrontation. Russia has a strategic culture that is deeply rooted in its history and geography, one that is fairly stable with respect to the prevailing threat perception and Russia's quest for great power status. However, this strategic culture did undergo some notable changes after the dissolution of the Soviet Union, when Russia's imperial ambitions subsided and the role of military strength as a source of power declined, being replaced by a new focus on economic power.

This article is not intended to be a comprehensive analysis of the evolution of Russian strategic culture. Rather, I use it as a basis for analyzing Russia's behavior in the post-Cold War era, particularly regarding its strategic aims toward the West, through an examination of Russian strategic and doctrinal papers, as well as statements of Russian leaders. Special emphasis will be placed on the changing perception of military power versus economic power, because this is the area in which the most significant changes in Russia's strategic culture have taken place. Ultimately, having abandoned its mission to spread Communist ideology, Russia is simply behaving like any other great power that is trying to find its place after having gained in relative strength. At the same time, however, Russia is particularly sensitive to Western actions due to its strategic culture, and feels challenged by Western goals of promoting liberal democracies and market economies.

Among the strategic implications for the West that this analysis suggests is that it is possible for the West to engage in compromise and constructive engagement with Russia. In a globalized world, it is just as much in Russia's interest as it is in the interest of

2 Ted Galen Carpenter, "What Russia Wants," The American Conservative (22 September 2008); available at www.amconmag.com/article/2008/sep/22/00006/. 
the West to not isolate Russia, but rather to respect its geopolitical role and give it its say on the international stage. In the long run, there is a chance to overcome the mindset of the Cold War era that pitted a monolithic Eastern Bloc against the democratic West. The acceptance of the idea of special spheres of interest for either the EU or Russia would be severely counterproductive to this aim, because it would cement the notion of a divided Europe.

\section{The Concept of Strategic Culture}

Realists may argue that national security strategies, foreign and security policy concepts, and military doctrines are solely defined by the main pillars of power: military might, economic strength, and technological and geostrategic factors. This realist approach, however, is unable to provide an explanation for either suboptimal or seemingly irrational behavior on the part of a state. Such actions might arise out of missionary attitudes, "misperceptions of balance of power or the intentions of other states, [or] exaggerated beliefs in both offensive and defensive strategies." The concept of strategic culture can help explain why states might act in ways that are, by realist standards, irrational.

In the 1960s Almond and Verba argued that "political culture" includes commitments to values and institutions, including ideas about morality and the use of force. It thus defines the perception of the role of a state in global politics. ${ }^{4}$ Drawing on this scholarship, in 1977 Jack Snyder introduced the concept of "strategic culture" into the realm of modern security studies. Snyder argued that Soviet strategic culture provided the context for understanding the intellectual, institutional, and strategic-cultural determinants of the actions of the Soviet state. He saw the development of Soviet nuclear doctrines as products of organizational, historical, and political contexts and of technological constraints. Snyder contended that strategic culture was "a set of semi-permanent elite beliefs, attitudes, and behavior patterns" that provided a lens through which policymakers viewed new security developments. ${ }^{5}$ Later, Duffield noted that a state's strategic culture defines the basic foreign policy goals and objectives that are to be pursued (reflecting state interests and identity) and shapes elite and public perceptions of the international environment. It also determines the type of policy options that are seen to exist, and influences the evaluation of these options. There are at least three levels of political culture: "the cognitive, which includes empirical and causal beliefs; the evaluative, which consists of values, norms and moral judgment, and the expressive

3 Henrikki Heikka, Strategic Culture and the English School, Working Papers 33 (Oslo: Finish Institute of International Affairs, 2002), p.5.

4 Gabriel Almond and Sidney Verba, The Civic Culture: Political Attitudes and Democracy in Five Nations (Boston: Little, Brown, 1965), 11-14.

5 Jack Snyder, The Soviet Strategic Culture: Implications for Nuclear Options (Santa Monica, CA: RAND Corporation, 1977), 8. 
or affective, which encompasses emotional attachments, patterns of identity and loyalty, and feelings of affinity, aversion, or indifference."

Although Snyder and others see strategic culture as somehow static or slow to change, newer publications concede that dramatic shocks may lead to more rapid alterations in beliefs, attitudes, and behavior patterns. ${ }^{7}$ This might happen when "dramatic events or traumatic experiences [such as revolutions, wars, and economic catastrophes]" discredit previously held notions. ${ }^{8}$ Today, most political scientists define strategic cultures as the "property of collectivities rather than simply of the individuals that constitute them." Alastair Iain Johnston claims that strategic culture is persistent if preference ranking is persistent. A high correlation between strategic preferences and actual strategic behavior is an indicator for the applicability of a strategic culture concept. ${ }^{10}$ Johnston also pointed out that when looking at the concept of strategic culture, one has to bear in mind that there might be a difference between declared and secret doctrine. $^{11}$

The weakness of the strategic culture concept is best described by Colin Gray, who writes, "social science has developed no exact methodology for identifying distinctive national cultures and styles."12 There is also no common definition of strategic culture. Despite these limitations, strategic culture still seems to be a promising approach to gain a better understanding of strategic behavior, and offers a more nuanced picture than does a solely realist approach.

\section{The Framework of Russian Strategic Culture}

Russian strategic culture is not just a product of its military culture, nor is that the only area where the influence of its strategic culture is felt. It has also been strongly influenced by Russia's political and foreign policy cultures, which both had a strong influence on Russia's economic culture. "How political power is defined, acquired, legitimized and used" and "how the outside world is regarded and addressed" are thus deci-

6 John S. Duffield, World Power Forsaken: Political Culture, International Institutions, and German Security Policy after Unification (Stanford, CA: Stanford University Press, 1999), 23.

7 Germany's "out of area" military engagement in the Balkans in the 1990s to end genocide and ethnic cleansing may serve as an example of such a shift.

8 Duffield, World Power Forsaken, 23.

9 Ibid.

10 Alistair Iain Johnston, Cultural Realism, Strategic Culture and Grand Strategy in Chinese History (Princeton, NJ: Princeton University Press, 1995), 38.

11 Alistair Iain Johnston, "Thinking about Strategic Culture," International Security 19:4 (1995): 37-39.

12 Colin Gray, The Geopolitics of Superpower (Lexington, KY: University Press of Kentucky, 1988), 42-43. 
sive factors in shaping a state's strategic culture. ${ }^{13}$ To gain a better understanding of Russian strategic culture, one has to look at the constitutive elements that had an impact on the development of the different aspects of this culture.

\section{The Historical Roots of Russian Strategic Culture}

Through all of Russia's history, from Imperial Russia to the Soviet era, the perception of being the object of aggressive imperial desires of neighboring states prevailed and shaped Russian threat perceptions. ${ }^{14}$ Hence this influenced Russia's ambitions to modernize its armed forces, its economy, and its political system in order to strengthen the state.

Threat Perception. Russia's history shows a long continuity of internal conflicts among the different principalities that constituted Russia and between different groups in Russian society, as well as military incursions from outside. From the foundation of the first east Slavic state, the "Kievan Rus" (862-1185), which was conquered and dominated by the Golden Hordes for two centuries (along with the other principalities that would eventually make up Russia), foreign powers repeatedly dominated or invaded Russian heartland. The Tartars burned Moscow in 1571; the Poles burned it again in 1610. In 1708, Charles XII, King of Sweden, invaded the Russia of Peter the Great and tried unsuccessfully to march to Moscow, suffering the same defeat as did so many others who harbored the same ambition. Russia suffered heavy losses from Napoleon's invasion in 1812 . With 100,000 Polish troops on his side, Napoleon actually succeeded in conquering Moscow, but eventually was forced to retreat.

The Russo-Japanese War of 1904-05 was another formative event for Russia's strategic culture. The Japanese Navy attacked the Russian Far East Fleet at Port Arthur before Japan's declaration of war was received by the Russian government. During the war, Russia lost most of its navy. The war ended with the first major victory of an Asian power over a European one in modern times. As a result of the war, Russia slipped into a severe economic crisis, which eventually led to the Bolshevik Revolution.

During the twentieth century Russia had to endure the trauma of two World Wars, along with the Polish invasion deep into Russia in 1920. These wars left deep scars in Russia's collective memory. Many internal conflicts, such as the catastrophic civil war that followed the October Revolution in 1917 as well as the breakup of the Soviet Union in 1992 were perceived as severe threats to the unity of Russia, as were the loss of large portions of its territory in the wake of the Soviet Union's dissolution, and the

13 Fritz W. Ermarth, "Russian Strategic Culture: Past, Present, and... in Transition?”, paper prepared for the Advanced Systems and Concepts Office of the Defense Threat Reduction Agency (31 October 2006), 3; available at www.fas.org/irp/agency/dod/dtra/russia.pdf.

14 Bruce W. Terry, "European Balance of Power: Will the European Union Upset Russia as it Balances the United States?" paper presented at the annual conference of the International Studies Association (San Diego, CA, 22 March 2006); available at www.allacademic.com/ meta/p98355_index.html. 
separatist wars in the Caucasus that followed. In many cases, external powers assisted one side or another within Russia, or were at least accused of doing so.

Prevailing Autocracy. Given the state's vast size and multi-ethnic nature, autocratic leadership seemed to be the type of governance that was best suited to cope with the wide range of external and internal threats that cropped up throughout Russian history. Peter the Great, the first tsar who tried to modernize Russia by adopting many European standards, did so after he had crushed an incursion. Even in the wake of this exercise of autocratic power, he created a senate and implemented other political reforms. The main thrust of his reforms, however, was aimed at strengthening Russia's technological and economic power in order to reform the military and to build up a modern Russian navy. Mainly in response to internal unrest, some social and political reforms took place in the nineteenth century, such as Tsar Alexander II's abolition of serfdom in 1861. Nevertheless, Russia remained a country that was significantly less free than most European great powers. Although the "Great Reforms" of Alexander II spurred industrialization, the state-planned industrial revolution was confined to the major cities. In the rest of Russia, the social system of feudalism remained in place. Democratic institutions on the state level (Duma) were not introduced until 1905, and remained powerless and dependent on the tsar. Since the end of the fifteenth century until the formation of the Soviet Union, all major reforms in Russia were spurred by the question of how to obtain money and increase the strength of the armed forces. In the final analysis, all reforms were dictated by foreign and military policy needs. ${ }^{15}$

In the aftermath of the civil war in 1917, "Communists represented only a tiny minority." This "made the establishment of dictatorial power a necessity." Later, the dictatorship was justified "by stressing the menace of capitalism abroad." ${ }^{16}$ Seventy years of totalitarian Communist rule cemented the autocratic system. In the perception of many Russians, this system was a system powerful enough to repel the Nazi invasion and to enable Russia to become a superpower during the Cold War.

Pursuit of Great Power Status. There is no consensus about when Russia attained great power status; instead, Russia can be said to have followed gradual process toward this status over time. ${ }^{17}$ An explanation for Russia's drive for expansion may be geography. Russia's ill-defined geographic boundaries not only cultivated a fear of vulnerability, but also nourished "an appetite for achieving security and status by expansion. ${ }^{, 18}$ Besides geography, religion and ethnicity may also have played a role in Rus-

15 Jurij Pivovarov, "Politieskaja istorija Rossii," cited in Falk Bomsdorf, Russland: Rückkehr in die Weltarena (Berlin: SWP-Zeitschriftenschau, 2003), 14.

16 George Kennan, "The Sources of Soviet Conduct," Foreign Affairs (July 1947); available at www.foreignaffairs.org/19470701 faessay25403/x/the-sources-of-soviet-conduct.html.

17 Iver B. Neumann, "When Did Russia Become a Great Power? Realist, Constructivist and Post-Structuralist Answers," paper presented at the annual conference of the International Studies Association (Chicago, 28 February 2007); available at www.allacademic.com/meta/ p179679_index.html.

18 Ermarth, "Russian Strategic Culture," 4. 
sia's quest to be a great power. Russia adopted Orthodox Christianity in 988, and eventually became the "bastion of Orthodoxy" after Constantinople fell to the Turks in 1453. Ivan III, who became tsar of Moscow in 1462, united most of the Russian Slavs. His marriage to the niece of the last Emperor of Byzantium (Second Rome) gave him the claim to be the successor to the Roman Caesars. Moscow, the Third Rome, was seen by Orthodox Christians as the last remnant of the true Christian civilization. Ivan IV, who became "the first tsar of all Rus" in 1547, started Russia's imperial expansion to the East, which enlarged Russia to the Pacific in the seventeenth century. So, as early as 1600 , "military power became the chief institutional foundation of Russian statehood." 19

At the beginning of the eighteenth century, Peter the Great set Russia on the path to great power status with his buildup of Russia's military and economic strength accompanied by his policy of Westernization. Tsarina Catherine the Great expanded the Russian Empire even further to the Black Sea and participated in the partition of Poland. With the fall of Napoleon, Alexander I was celebrated as the "savior of Europe." Russia took part in the Congress of Vienna in 1815, where the boundaries of Europe were redrawn. After the Congress, Russia was considered to be "a power with system-wide interests as well as a say in matters pertaining to the management of the system" - i.e., one of the leading powers in Europe. ${ }^{20}$ For most of the twentieth century, until the disintegration of the Soviet Union in the early 1990s, Russia was seen as a global power.

At present, there are different approaches to evaluating great power status. According to the realist view, great powers are defined not by their behavior, but by their capability to maintain "their autonomy in the face of force that others wield and [to take] a variety of actions to pursue other goals they may have." ${ }^{21}$ A constructivist would rather refer to "the degree in which it is a dominant member of formal and informal international institutions." 22 Alexey Pushkov identified three factors defining Russia as a great power: its nuclear and conventional weapons, its importance to the global economy (by its possession of significant natural resources), and its "indispensability, in part due to its geopolitical location, for solving critical world conflicts."23 One may add that Russia's role in global affairs is bolstered by its permanent seat on the UN Security Council. The high potential Russia has in the fields of science and

19 Ibid., 5.

20 Neumann, "When Did Russia Become a Great Power?", 2.

21 Karen Adams, "Great Power: What Will It Take?" (paper presented at the annual conference of the International Studies Association, Montreal, 17 March 2004); available at www.allacademic.com/meta/p73660_index.html.

22 Neumann, "When Did Russia Become a Great Power?", 6.

23 Nikolas Gvosdev, “Because It Is': Russia, The Existential Great Power," The National Interest; available at www.gwu.edu/ sigur/assets/docs/major_powers_091407/Gvosdev_on_ \%20Russia.pdf 
technology may also be reckoned as a factor adding to its great power status. ${ }^{24}$ So, in both the realist and the constructivist view, Medvedev's Russia can be considered a great power.

\section{External Influences and Russian Strategic Culture}

Geopolitical ideas such as those of Nicholas Spykman and Halford Mackinder-who both defined Russia's territory (Eurasia) as the central key that would affect the destiny of the world - laid the basis for a containment strategy against Russia and probably affirmed Russian threat perceptions. ${ }^{25}$ As Russia has no easily defendable geographical boundaries, it was always vulnerable to external attack. As George Kennan wrote of Russia's situation, "Here caution, circumspection, flexibility and deception are the valuable qualities." ${ }^{26}$ Defeat would have been a catastrophe in Russia's far-flung geography. Over time, a highly centralized, militaristic (but at the same time riskaverse political system) developed that relied on the idea of mass forces that could knowingly be sacrificed. The continuation of Russian strategic culture despite all the strategic changes during its history is impressive, and it "certainly arises in the main from a political culture and psychology shaped by geography." 27 This continuity has to be kept in mind when discussing possible changes in Russia's strategic culture.

As was mentioned above, Russia's vast size and wide range of threats seemed to suggest autocracy as the only feasible mode of governance. It was not before the first years of President Yeltsin, in the 1990s, that genuine democratic reforms started and market reforms took hold. The same process took place in other post-Communist countries, but with the difference that those countries wished to join Euro-Atlantic institutions and thus accepted Western democratic values and standards. Russia rejected this model of external "management by objectives," instead pursuing a "transition without a destination." It did not want to join existing organizations on conditions defined by others. ${ }^{28}$ For many Russians, the early years of transition are associated with the economic downfall of Russia, the unchecked theft of the wealth of the Russian people by a few oligarchs, and the loss of Russia's great power status. Therefore, democratic reforms never achieved any real traction, or as Boris Kagarlitsky, a senior researcher from the Russian Academy of Sciences named it, a "neo-liberal autocracy" emerged. $^{29}$

${ }^{24}$ Sergei Kortunov, "Should Russia Claim Great Power Status," RIA Novosti (25 September 2006); available at http://www.spacewar.com/reports/Should_Russia_Claim_Great_Power_ Status_999.html.

See Helen R. Nicholl and Nicholas J. Spykman, The Geography of the Peace (New York: Harcourt, Brace, and Co., 1944), and Halford J. Mackinder, "The Geographical Pivot of History," The Geographical Journal (London, April 1904): 421-37.

${ }^{26}$ Kennan, "The Sources of Soviet Conduct."

27 Ermarth, "Russian Strategic Culture," 4.

28 Alexander Lomanov, "Transition Without a Destination," Russia in Global Affairs 6:2 (April-June 2008): 20-34; available at http://eng.globalaffairs.ru/numbers/23/1192.html.

29 Boris Kagarlitsky, Russia Under Yeltsin and Putin: Neo-Liberal Autocracy (London: Pluto Press, 2002). 


\section{Articulations of Russia's Foreign Policy}

\section{The Predominance of Realism}

After the collapse of the Soviet Union, a period of strategic irrelevance and internal dissolution followed. In the first half of the 1990s, realism was not the prevailing school of thought in Russian foreign policy circles. Russia was in a sorry state, and thus the focus of Russian policy was placed squarely on its internal political and economic problems. Integration into the world economy was seen as a solution to these problems. Can this choice be understood as representing a change in Russia's strategic culture? One has to look more closely at what shaped Russian policy after the Cold War. One way to do so is to look at the prevailing intellectual school of international relations in Russia and how it influenced the strategic community. Tatyana Shakleyyina and Aleksei Bogaturov point out in their analysis of Russian international relations scholarship that realism has regained "the status of a leading intellectual movement in Russia" since the 1990s. ${ }^{30}$

After the political upheaval of 1994-95, the idea of a balance of power re-emerged. Unipolarity was perceived as harmful, although at the same time it was seen as something that had to be accepted. ${ }^{31}$ Although realism is made up of different schools, there is one element that is common to all branches - a strong geopolitical approach that is "characteristic of the Russian cultural tradition." The different approaches are "united by their understanding of the power superiority of the U.S." They also agree that national interests and the will to defend them must constitute the foundation for Russian foreign policy strategy. But whereas the structuralists assume that coexistence with the West is possible, and that adaptation is a "necessary choice" for Russia, the geopoliticians believe that the intention of the West, specifically the United States, is "to destroy the coherence and territorial integrity of Russia." 32

These two different assumptions - which are based on radically different perceptions of the external threat - of course have implications on the recommendations that one would make for Russia's foreign policy. Some advocate concentrating on the former Soviet area, while others are in favor of developing a Russia-China axis to balance the U.S. Still others advocate an alliance with Western countries to address more serious common threats, such as terrorism and proliferation of weapons of mass destruction (WMD). Regardless of the different recommended strategies, however, no one abstains from great power thinking. Thus one can state that Russia's strategic culture did not fundamentally change in the early 1990s; rather, it "hibernated" during a period of diminished pressure from the outside and weakness on the inside.

30 Aleksei D. Bogaturov and Tatyana A. Shakleyyina, "The Russian Realist School of International Relations," Communist and Post-Communist Studies 37:1 (March 2004): 37.

31 Ibid., 38.

${ }^{32}$ Ibid., 40-42. 


\section{Threat Perception in the Post-Cold War Era}

During the early Yeltsin years, the United States was no longer perceived as a threat to Russia's survival, but rather as a state that could assist Russia's development. During this period, the military was not envisioned as fighting against an external enemy, "but may be needed to keep Russia from disintegration."33 Disintegration —or to reformulate it, threats against Russia's territorial integrity — was perceived as a severe threat from the onset. During this period when Russia was weak, it once again felt the historically deep-rooted threat to its existence. The West did not reassure Russia that it was not at risk, but rather criticized it for its fight against separatist forces in the first Chechen War, which started in 1994.

Although the National Security Blueprint of 1997 states that "the danger of direct aggression against the Russian Federation has decreased," it nevertheless makes it a priority "to ensure the inviolability of [Russia's] borders and territorial integrity." Russia feared that other countries would attempt to hinder it from becoming a key node in a multipolar world through "actions aimed at destroying the ... territorial integrity, including actions involving the use of inter-ethnic, religious, and other internal contradictions." 34 "Deliberate and purposeful interference by foreign states and international organizations in the internal life of Russia's peoples" were identified as a means to achieving such disruptions. "Powerful groupings of armed forces in regions adjacent to Russia's territory" were considered as a threat to its national security, even if they had no aggressive intentions. Their sheer presence was felt to constitute a potential military danger. NATO's "expansion" was explicitly mentioned as threatening a "new split in the continent" in the light of its strike groupings and the absence of an effective "multilateral mechanism for maintaining peace." 35 Whereas the West defines "threat" as the combination of the capability and the intention to act, the predominant definition of "threat" within Russian strategic culture is the control of space by another power.

The National Security Concept of 2000 points this out even more explicitly: "some states have stepped up their efforts to weaken Russia's position in the political, economic, military and other spheres. The attempts to ignore the interests of Russia when tackling major problems of international relations ... can undermine international security and stability...." ${ }^{36}$

Russia's military doctrine, which also dated from 2000, underwent a revision ordered by Putin in 2005. In January 2007, the chief of the general staff of the Russian armed forces, General Baluyevsky, presented elements of the upcoming doctrine. The chief of the general staff perceived the main threats to be the U.S.'s "desire to get a foothold in regions where Russia traditionally is present," along with NATO enlarge-

33 Ermarth, "Russian Strategic Culture," 13.

34 Boris Yeltsin, "Russian National Security Blueprint," Presidential Edict no. 1300, approved by Russian Federation on 17 December 2007, Rossiiskaya Gazeta (26 December 1997); available at www.fas.org/nuke/guide/russia/doctrine/blueprint.html.

36 Vladimir Putin, "National Security Concept of the Russian Federation," Rossiiskaya Gazeta (18 January 2000); available at www.fas.org/nuke/guide/russia/doctrine/gazeta012400.htm. 
ment, the Alliance's involvement in local conflicts near the Russian border, and "hostile information on Russia's policies." ${ }^{37}$

In his address to the Federal Assembly in 2007, Putin expressed his notion of threats to Russia's sovereignty: "To be frank, our policy of stable and gradual development is not to everyone's taste. Some, making skilful use of pseudo-democratic rhetoric, would like to return us to the recent past," while others deploy such rhetoric "in order to deprive our country of its economic and political independence." 38 Putin also indirectly accused non-governmental organizations and other recipients of Western money of being the spearhead of this effort, claiming: "There has been an increasing influx of money from abroad being used to intervene directly in our internal affairs." ${ }^{39}$ Thus Putin, even in a phase of relative strength of Russia, saw a threat to Russia similar to the "color revolutions" that took place in the post-Soviet space in the first decade of the new century.

The Russian leadership obviously feared that it was soon to be encircled by American military bases. NATO's enlargement to the East, the massive long-term U.S. presence in Central Asia in the aftermath of the terrorist attacks of 11 September 2001, and the color revolutions in Georgia (2003), Ukraine (2004), and Kyrgyzstan (2005) all gave support to this notion. Russia in consequence assisted the elites of Central Asian countries who were also alienated from the United States' support for the wave of democratic revolutions in the region. ${ }^{40}$ The unfolding of this process is a typical example of the so-called "security dilemma," a term coined by John Herz in the 1950s. ${ }^{41}$ One power tries to enhance its security or the security of its allies by enlarging one or more realms of its power basis, thus directly influencing the security perception of another power, which in response tries to alter the power equation by its reaction. According to international relations theorists, the failure of communication leads to a loss of trust and eventually to confrontation.

The fear of being the object of the United States' geopolitical ambitions is broadly shared by the Russian population. 49 percent say the escalation of the Georgian conflict was the fault of the United States because it wanted to gain control of Russia's neighbors, 74 percent of the population see Georgia as the victim of U.S. geopolitical ambitions, and 70 percent hold the opinion that Russia did everything possible to avoid

37 Marcel de Haas, "Russia's Upcoming Revised Military Doctrine," Power and Interest News Report (26 February 2007); available at www.pinr.com/report.php?ac=view_report\&report $\mathrm{id}=622$ \&language_id $=1$.

38 Vladimir Putin, "Annual Address to the Federal Assembly," 26 April 2007; available at www.kremlin.ru/eng/speeches/2007/04/26/1209_type70029type82912_125670.shtml.

39 Ibid.

40 Andrei Kazantsev, "Russian Policy in Central Asia and the Caspian Sea Region," EuropeAsia Studies 60:6 (August 2008): 1073-1088.

41 John H. Herz, "Political Realism and Political Idealism," American Sociological Review 16 (1951): 733-34. 
the escalation. The war is not seen as a conflict between Georgia and South Ossetia, but as a proxy-war. ${ }^{42}$

Russian scholars often define a truly sovereign state as one "whose goals and methods, at home and abroad, are made solely on the basis of calculation of national interest rather than because of external pressure to conform to behavioral norms. ${ }^{43}$ Having this definition in mind, the rising dominance of Western norms and values as well as the increasingly unilateral actions by Western powers (and especially by the United States) during the 1990s have to be understood as threats to Russia's sovereignty. As a consequence, the Russian Foreign Policy Concept of 2000 identifies "a unipolar structure of the world with the economic and power domination of the United States" as one of the major threats to Russian interests. ${ }^{44}$ This view is perpetuated in the 2008 Foreign Policy Concept. ${ }^{45}$

In the post-Cold War era, all activities affecting Russia's sovereignty and territorial integrity were perceived as major threats, irrespective of their origin. Thus separatism, those forces fostering separatism, military encirclement of Russia, etc. were all seen as powers hindering Russia from regaining its rightful historical position as a proud great power, and were viewed as being aimed directly at the heart of Russian interests.

\section{Russia's Foreign Policy Interests}

During the early Yeltsin years many scholars and politicians believed that integration into the community of developed countries would best serve Russia's interests, even if it did involve a tacit acceptance of unipolarity. With only a few exceptions, the realist concepts of "great power" and "balance of power" were not mentioned. In fact, Russian interests were not defined in a global context. ${ }^{46}$ During this period Russia's strategic culture seemed to change. The new governing assumption was that Russia should do more than learn from the West, as it did during the times of the tsars; it should now work to integrate with the West and adopt its values, such as democratic politics, the rule of law, and market economics. Still, Russia had aspirations to return to its role as a key player on the international stage. This hope was based on its permanent seat on the United Nations Security Council, its nuclear capabilities, its vast natural resources, its capability to stabilize Eurasia, and its geopolitical function as a bridge between Europe and Asia.

${ }^{42}$ Boris Dubin, "Fernsehkrieg und echter Krieg - Russland: Der Kaukasus-Konflikt in den Köpfen,” Osteuropa (Berlin) 11 (2008): 72.

43 Jeffrey Mankoff, "Russia and the West: Taking the Longer View," The Washington Quarterly (Spring 2007): 128.

44 Vladimir Putin, "The Foreign Policy Concept of the Russian Federation," 28 June 2000; available at www.fas.org/nuke/guide/russia/doctrine/econcept.htm.

45 Dmitry Medvedev, "The Foreign Policy Concept of the Russian Federation," 28 June 2008; available at http://www.maximsnews.com/news20080731 russiaforeignpolicyconcept108073 11601.htm.

${ }^{46}$ Bogaturov and Shakleyyina, "The Russian Realist School of International Relations," 44. 
The reaction of the West to the first Chechen war (1994-96) and NATO's first round of eastward enlargement (accession negotiations were offered to Poland, the Czech Republic, and Hungary during the NATO summit in Madrid in 1997) showed the breadth of the divide between Moscow and Washington. Russian politicians and scholars began working to define the country's geostrategic priorities. On the one hand, integration with the West was no longer a path most Russians were willing to follow. Yet there was no evident desire to actively confront the West.

Yevgeny Primakov, who had become Russia's Minister of Foreign Affairs in 1996 and was in line to become prime minister in 1999, designed Russia's new foreign policy approach. Whereas the academic community was still divided over whether to devote scarce resources to maintaining a place for Russia as a power in a multipolar world or to acknowledge the United States' role as the sole remaining great power and solve domestic problems first, Primakov announced that "the concept of a multipolar world had already become part of the official strategy of the Ministry of Foreign Affairs. ${ }^{, 47}$ The main objective seems to have been to prevent Russia's isolation in the international system since, in the Kremlin's view, multipolarity "implies a world of states that are more or less equal, if not in their inherent power capabilities ... then at least in their responsibility for upholding global order." ${ }^{48}$ Russia wanted to consolidate its position as a great power and to develop "equal partnership with the other great powers - the centers of economic and military might." 49

To some, the special attention devoted by Russia at this time to the former Soviet republics and the ethnic Russians living there was a cause for significant concern. As early as 27 September 1994, Boris Yeltsin told the United Nations that "Russia's priority interests lie in the newly independent nations of the former Soviet Union.. 50 Multifaceted interaction within the CIS region remains an absolute priority for Russia. Today, Russia does not officially claim this region as being part of its exclusive sphere of influence, but rather skirts the issue thus: "There are regions in which Russia has privileged interests. These regions are home to countries with which we share special historical relations and are bound together as friends and good neighbors." ${ }^{, 51}$ Foreign Minister Lavrov, for example, called "upon everyone to act in this region in a legitimate and transparent manner, without damaging stability." 52 In other words, whoever

47 Ibid.

48 Mankoff, "Russia and the West: Taking the Longer View," 128.

49 Yeltsin, "Russian National Security Blueprint."

50 John M. Goshko, "Yeltsin Claims Russian Sphere of Influence," The Washington Post (27 September 1994); available at http://www.friends-partners.org/oldfriends/news/wsummit/ regional.peacekeeping.html. After this point, Russia made the noteworthy distinction between "post-Soviet space" and the "CIS-region," which does not include the Baltic States. Dmitry Medvedev, "Russia Won't Accept Unipolar World," television interview given on 31 August 2008; available at www.globalsecurity.org/wmd/library/news/russia/2008/russia080831-medvedev01.htm.

52 Sergei Lavrov, "Transcript of Remarks by Russian Minister of Foreign Affairs at the Myrdal Lecture," Geneva, 12 February 2008; available at www.ln.mid.ru/brp_4.nsf/f68cd37b84711 611c3256f6d00541094/44d42bb592ce7921c32573ee00274e6a?OpenDocument. 
wants to do business is welcome as long as he does not interfere in domestic issues. Within that region, Ukraine - with its large Russian population and its strong cultural and economic ties to Russia-is of utmost importance. According to a former British ambassador to Moscow, the West can expect "that Russia would exert itself mightily, risk a great deal and pay a high price to prevent Ukraine from becoming, as Russians would see it, a platform for American power." 53

The decision to focus on its nearby region and not to challenge the West globally was most likely made in the light of Russia's discouraging experiences in Afghanistan (1979-89), the harmful arms race that led to the collapse of the Soviet Union, and the huge costs of the Chechen war. A confrontational policy towards the West would have placed an even greater strain on the resources desperately needed for domestic consolidation. The dominance of domestic issues can be seen throughout many annual declarations of the presidents to the Federal Assembly.

After the terrorist attacks of 11 September 2001, Russia allowed U.S. troops to be stationed in Central Asia, joined the Proliferation Security Initiative, and supported the United States' approach towards Iran and North Korea's nuclear programs. ${ }^{54}$ Many observers at that time misinterpreted this broad range cooperation as a signal that Russia again wanted to integrate into the West. But this behavior was not surprising at all. It was simply an instrumental decision in line with Russia's doctrinal papers that was entirely coherent in terms of its strategic culture. The U.S. involvement in Afghanistan was at first a unique opportunity to let someone else fight the Taliban, who by then had already become a threat to most Central Asian states. ${ }^{55}$

In 2002, Yevgeny Primakov wrote, "Russia can and should seek equal relations of partnership with all countries, look for and find areas of coinciding interests. Where interests do not coincide ... we should try to find solutions that, on the one hand, protect Russia's vital interests and, on the other, do not lead to slipping back to confrontation., ${ }^{, 56}$ Nevertheless, relations between the West and Russia became more and more strained as Russia pushed ever more insistently to return to great power status. Or, as Foreign Minister Sergey Lavrov pointed out in 2006, "I believe that rapid restoration of Russia's autonomy in its foreign affairs is one of the factors complicating relations between our countries, because not everyone in the United States has gotten used to that." Still, Lavrov conceded that on the presidential level a good relationship based on mutual respect had been developed, which permitted the pursuit of "compromise solutions to many problems, both bilateral and international. ${ }^{, 57}$ Russian leadership sought compromise throughout the post-Cold War era, even during periods of heightened

53 Roderic Lyne, "Reading Russia, Rewiring the West," opendemocracy.net (12 October 2008); available at www.opendemocracy.net/Russia/article/Reading-Russia-Rewiring-the-West.

Mankoff, "Russia and the West: Taking the Longer View," 131-33.

55 Kazantsev, "Russian Policy in Central Asia and the Caspian Sea Region," 1074-81.

56 Yevgeny Primakov, "Turning Back Over the Atlantic," International Affairs: A Russian Journal of World Politics 6 (2002): 69.

57 Sergei Lavrov, "Speaking Notes at the Los Angeles World Affairs Council," talk delivered on 25 September 2006; available at www.embrusscambodia.mid.ru/pr/pr001-e.html. 
rhetoric and increased references to Russia's military strength. There are two major reasons for this behavior. First, Russia lacks strategic allies that would embolden it to attempt to chart its own course. ${ }^{58}$ Second, according to Yeltsin, "Russia's national interests in the economic sphere are crucial. ... A comprehensive solution of the problems connected with implementing Russia's national interests is possible only on the basis" of a functioning economy. ${ }^{59}$

In order to (re)gain economic power, the Russian government established a framework for energy expansion and export in 2003. In December 2005 Putin presented a "National Energy Strategy" to the Russian Security Council, and claimed that Russia "must become an 'energy superpower' to regain political leadership in the world." 60 Nevertheless, the Russian leadership always recognized the necessity to diversify Russia's economy to become less dependent on commodities.

Medvedev approved a new "Foreign Policy Concept" for Russia on 28 June 2008. This concept declared that the chief objectives that should be achieved by Russia's foreign policy efforts are "to ensure national security, to preserve and strengthen its sovereignty and territorial integrity, to achieve strong positions of authority in the world community that best meet the interest of the Russian Federation as one of the influential centers in the modern world, ... to create favorable conditions for the modernization of Russia, ... to promote good neighborly relations, ... [and] to provide comprehensive protection ... of Russian citizens and compatriots abroad...."61 Thus Medvedev in general points to the same objectives as his predecessors did: returning Russia to great power status, maintaining strong influence in its region, and pursuing ambitions to play a significant role on the international stage. Economic power is seen as prerequisite to all of these goals. In this document Medvedev used almost the same language of geopolitics (states seeking power and pursuing national interests while subject to a balance of power) as did the "Foreign Policy Concept" of 2000.

In Medvedev's view, network diplomacy has replaced bloc-based approaches to international problems. These approaches still linger in the post-Cold War European security architecture, but they should be replaced by a "democratic system of regional collective security and cooperation" that spans from Vancouver to Vladivostok. The strategic stability issue also needs a new approach, because the framework of RussiaU.S. relations is perceived as being no longer sufficient. ${ }^{62}$ Putin had already hinted at this necessity in his speech at the $43^{\text {rd }}$ Munich Conference on Security Policy when he claimed, "we must seriously think about the architecture of global security." 63

58 Ariel Cohen, “Domestic Factors Driving Russia's Foreign Policy,” Backgrounder No. 2084 (The Heritage Foundation, 19 November 2007), 2, executive summary.

59 Yeltsin, "Russian National Security Blueprint."

60 Victor Yasmann, "Russia: Moscow's New Nuclear Strategy," Radio Free Europe/Radio Liberty (15 February 2006); available at www.rferl.org/content/article/1065789.html.

61 Medvedev, "Foreign Policy Concept."

62 Ibid.

63 Vladimir Putin, Speech at the $43^{\text {rd }}$ Munich Conference on Security Policy, 10 February 2007; available at www.securityconference.de/konferenzen/rede.php?sprache=en\&id=179. 
In Berlin, on 5 June 2008, Medvedev proposed a restructuring of the European security architecture, recommending the "drafting and signing [of] a legally binding treaty on European security in which the organizations currently working in the EuroAtlantic area could become parties." He claimed that all the parties involved need to "break the vicious circle of unilateral action and reaction." He suggested considering "holding a general European summit to start the process of drafting this agreement," and repeated his proposal in different high-level formats. ${ }^{64}$ According to an "Immediate Report" of the NATO Defense College, Medvedev's proposal reflected "a new Russia." ${ }^{65}$ The more pro-Russian countries like Italy, Germany, France, and Spain commented positively on this proposal, while the pro-Atlantic Think Tank Cicero Foundation saw hidden objectives (dividing the NATO allies, binding NATO not to undertake humanitarian interventions, etc.). ${ }^{66}$ Others saw the Russian agenda as consisting of "no further Western enlargement, disarmament deals that constrain Western activities ... and more control for itself over former Soviet territory.",67

Medvedev's proposal — which is in line with Russia's strong push for a multipolar world-has primarily been seen as a Russian attempt to contain the power of the United States through forming a variety of coalitions, including coalitions with a postmodern Europe. It thus follows the international relations concept of balance of power, in which states aim to prevent a unipolar world in order to avoid one nation becoming strong enough to enforce its will on other nations. Interestingly, one can also find many references to the importance of the United Nations and the rule of law in almost all Russian doctrinal papers. Again, these approaches to international relations can most likely be seen as instruments to contain U.S. power, but they also hold appeal for several large European nations.

Yeltsin's flirtation in the early 1990s with integration and Russia's response to the attacks of $9 / 11$ gave birth to the myth that Russia had adopted integration with the West as a fundamental strategic choice. This would have been a major change in Russia's strategic culture, a change that obviously never took place. Today we have to cope with a Russia that is still pursuing its interests according to the rules of the Hobbesian order. Thus, as Robert Kagan has expressed it, "Russia's complaint is not with

${ }^{64}$ Dmitry Medvedev, Speech at Meeting with German Political, Parliamentary, and Civic Leaders, Berlin, 5 June 2008; available at www.ln.mid.ru/brp_4.nsf/e78a48070f128a7b432569 99005bcbb3/c080dc2ff8d93629c3257460003496c4.

${ }^{65}$ Andrew Monaghan, "Russia Will Propose a new Foreign Policy Concept to NATO," NATO Defense College Immediate Report (Rome, July 2008).

${ }^{66}$ Marcel H. Van Herpen, "Medvedev's Proposal for a Pan-European Security Pact," Cicero Working Paper WP08-03 (Paris/Maastricht, October 2008).

${ }^{67}$ Alyson Bailes, "New European Security Treaty Worth Trying," Utrikesbloggen (12 January 2009); available at www.utrikesbloggen.se/index.php?option=com_content\&task=view\&id= $1705 \&$ Itemid $=27$. 
this or that weapons system. It is the entire post-Cold War settlement of the 1990s that Russia resents and wants to revise." 68

When judging Medvedev's proposal for a new security architecture, the West has to keep in mind that Russia most likely views this proposal as just another instrument to contain U.S. power. Nevertheless, a blunt rejection of this proposal is not in the interests of most European nations, and probably not even the United States. The price that will have to be paid if the world is once again divided into confrontational blocs will be high. A new post-Cold War security architecture linking Russia and the CIS region with economic and legal ties while granting Russia its desired great power status on the international stage should be given thorough consideration.

\section{The End of Ideology?}

The promising start of Russia's integration into the West during the first half of the 1990s came to a halt when anti-Western parties such as the Liberal Democratic Party and the Communist Party gained successes in parliamentary elections. ${ }^{69}$ Western models of democratic and economic liberalism had lost their attraction due to the economic turmoil that accompanied the collapse of the Soviet Union. ${ }^{70}$

In the mid-1990s, Russia started to consolidate as a state. National ideology, nationally oriented policies, and the idea of Russia as a great power re-emerged and became key subjects for appraisal by all major political parties. Sergei Kortunov has described the school of thought that emerged from this era as "enlightened democratic patriotism" that "will incorporate the ideas of an open society, individual freedom, [and] strong and responsible state power." ${ }^{71}$ Russia's leadership thus hoped to overcome the nation's crisis of identity, which had increased in intensity after the collapse of the Soviet Union. In 2007, "sovereign democracy"-a term first used by Vladislav Surkov as a modernization paradigm in 2006, describing the notion of being an independent sovereign state that is free of foreign influence- became the new national ideology with its introduction into the platform of the United Russia party. According to this idea, only a state with a strong military can be considered a sovereign state. In order to have a strong military, the state has to have state control over the export potential of the economy; only then will the state have a sustainable national future. Through the pursuit of the ideal of sovereign democracy, it was thought, the chaos and disorder of the 1990s could be avoided. This mode of statehood is seen as preventing specific parties or groups from taking control of the state, and as breaking the reaction-revolution pattern. It is thus a safeguard against the so-called "color revolutions." But even

68 Robert Kagan, "End of Dreams, Return of History," Policy Review No. 143 (June/July 2007): 5.

69 Mankoff, "Russia and the West: Taking the Longer View," 124.

70 A. Cohen, "Domestic Factors Driving Russia's Foreign Policy," 1, executive summary.

71 Sergei Kortunov, “The Fate of Russia: Several Observations on 'New' Russian Identity,” unpublished research paper, available at http://www.stanford.edu/group/Russia20/volumepdf/ Kortunov.pdf. 
this ideology does not define Russia as a nationalistic and imperialistic power; rather, it is aimed primarily at domestic politics.

By the year 2000, political scientist Alexander Yakovlev argued that the concept of a multipolar world had failed as a system to provide global peace and stability. The military intervention in Yugoslavia in 1999, the reactions of the West to Russia's war in Chechnya, and other actions had "demonstrated that the West did exist and act as a united pole" and thus "the West has been able to impose itself on others and to get away with its promotion of Western democratic and liberal ideas, even by means of military intervention." In order to prevent the West from "[ruling] the world unilaterally," the only chance for the non-Western "periphery" would be to unite. Other political scientists also saw a continuation of the era of bipolarity, in which "authoritarian ways of regulating world order are becoming increasingly common." ${ }^{, 72}$

During the last years of Putin's presidency, as the perception of the United States and the West in general as a threat re-emerged, the notion of Russia's return to great power status became a prominent idea and a driving factor in Russian foreign policy. Traditional notions of power continued to matter. The "ideology" of this revival of elements of Russian strategic culture "is essentially nationalism, replacing at least to a modest degree the role of communist ideology in Soviet times." ${ }^{, 73}$ In the wake of the financial crisis in the 1990s, which culminated in the "bankruptcy" of the Russian state on 17 August 1998, and the nation's obvious impotence to effectively counter the United States, Putin hoped to alleviate the culturally deep-rooted feeling of insecurity of the Russian people by emphasizing strength and unity. ${ }^{74}$ To achieve his goal he concentrated power in the executive branch of government (i.e., in himself). The executive gained control over state-owned enterprises and almost all phases of Russian politics. The legislative and judicial branches lost influence, as did the regional political leaders. ${ }^{75}$ The siloviki - "an informal network of government officials and businessmen ... who share similar political views, pursue a common policy agenda, and seek joint control over economic assets" - became a powerful group within the government. They promoted a strong centralized state, which would play a leading role in Russia's economy and on the international stage. This group is also characterized by the promotion of law and order and stability and a sharp disdain for democracy. ${ }^{76}$ Thus, Vladimir Putin had a powerful group backing his position of strength and unity, but he also had to pay tribute to them. His speech at the $43^{\text {rd }}$ Munich Conference on Security Policy may be seen as such an act of obeisance to his benefactors. ${ }^{77}$ Putin very openly addressed Russia's view of the global political environment, and elaborated the key points of Russian foreign and security policy that derived from it. Or, as László Póti

72 Bogaturov and Shakleyyina, "The Russian Realist School of International Relations," 46.

73 Ermarth, "Russian Strategic Culture," 15.

74 Mankoff, "Russia and the West: Taking the Longer View," 127.

75 Ian Bremmer and Samuel Charap, "The Siloviki in Putin's Russia," The Washington Quarterly (Winter 2006-07): 84.

76 Ibid., 86-89.

77 Putin, Speech at the $43^{\text {rd }}$ Munich Conference on Security Policy, 10 February 2007. 
put it: "He simply summarized well-known Russian security policy concerns and visions on unipolarity, U.S. unilateralism, international law and the use of force, NATO expansion, missile defense, etc. ${ }^{, 78}$ Nevertheless, his speech was seen as a return to Cold War rhetoric.

The Foreign Policy Concept of 2008 for the first time predicted that "global competition is acquiring a civilizational dimension which suggests competition between different value systems and development models within the framework of universal democratic and market economy principles." At the same time, the concept called for respect for the "national and historic peculiarities of each State in the process of democratic transformation." $" 79$

Nevertheless, Russia will not create an all-encompassing ideology similar to that of the Soviet model, even if its return to great power status - which goes along with an autocratic system - should prove to be sustainable. The Russian (or also the Chinese) model has less appeal to other countries than does the combination of liberal democracy and market economy. On the one hand, Russia has not been able to assemble a cohesive bloc of states that are willing to join it in attempting to pose a genuine challenge to the West. On the other hand, it cannot be foreseen whether future trends in economic and social development will create sufficient pressure to drive genuine democratization within Russia. ${ }^{80}$

Some analysts see the period of Russia's turn toward the West as having been brought to an end by the Georgian conflict, claiming that Russia could not be an enemy and partner of the West at the same time. Making compromises with an adversary in an authoritarian system would be seen as weakness, and weakness would be political suicide. ${ }^{81}$ This notion assumes that Russia viewed itself as an enemy of the West, but an examination of Russian papers on strategic doctrine offers no evidence for this assumption. Russia is simply behaving like any rising power that wants to have its say in international politics and is trying to limit the ambitions of other great powers in order to define its own position. With respect to the West, the war in Georgia was meant to be a clear signal of Russia's red line that should not be crossed. With respect to Kiev, the cradle of Russian statehood, the Kremlin's decisive move was also meant to be a warning. Since Russian forces have largely withdrawn from Georgia proper, an analogy with the expansionist Soviet Union seems far-fetched.

78 László Póti, "Evolving Russian Foreign and Security Policy: Interpreting the Putin-doctrine”, Acta Slavica Iaponica 25 (2008): 41; available at http://src-home.slav.hokudai.ac.jp/ publictn/acta/25/poti.pdf.

79 Medvedev, "Foreign Policy Concept."

80 Whether this pressure is desirable at the moment is questionable. According to the "democratization-war proneness-theory," states in transition to democracy are more prone to violence and war than stable authoritarian states, especially under the conditions of poverty. See Edward D. Mansfield and Jack Snyder, Electing to Fight: Why Emerging Democracies Go to War (Cambridge, MA: MIT Press, 2005).

81 Lilija Sevcova, "Ende einer Epoche-Russlands Bruch mit dem Westen," Osteuropa (Berlin) 11 (2008): 65-68. 
Some authors argue that Russia's reaction can be attributed to the authoritarian system that had been established during the preceding years. If the Ukraine and Georgia were to develop like Poland or Slovenia, then the argument in favor of authoritarian rule would be proven wrong, and the political class would thus feel threatened in its existence. ${ }^{82}$ What this argument fails to take into account is the fact that there has been a culture of authoritarian rule in Russia for centuries. Most Russians want to have a strong and powerful leadership. It was Putin's strong hand in Chechnya that earned him admiration, and it was Medvedev's and Putin's forceful response to Georgia's incursion into South Ossetia that gained both of them their highest levels of popular support. Medvedev's approval rating jumped from below 40 percent to more than 70 percent, almost as high as Putin's. ${ }^{83}$

After the Cold War, while the U.S. became the predominant global power, Russia was no longer simply a smaller Soviet Union that just had lost some of its territory - it truly fell out of the rank of the leading global powers. Today, Russia is readjusting its status. While some groups (for example, some within the siloviki) still perceive Russia as a small Soviet Union, others just want to regain great power status and formal global recognition. This process leads to clashes with the West, which had become unaccustomed to having another power challenge its dominance. The West has occasionally engaged in shrill rhetoric drawing on memories of the Soviet Union, while Russia has at times carried out symbolic acts that exaggerate its military power. Both approaches lead to mutual uncertainty. But in a sense, the Putin system seems simply to be a return to Russian norms, with the main difference being the presence of popular support for him and his successor.

As Samuel Huntington observed as early as 1993, "If, as the Russians stop behaving like Marxists, they reject liberal democracy and begin behaving like Russians but not like Westerners, the relations between Russia and the West could again become distant and conflictual." 84 Until recently, this prediction seemed to be coming true, as the economic strength of Russia relative to the West had increased because of the rise of commodity prices. But with the international financial crisis hitting Russia hard, the tone has softened significantly. In a certain way, Russia behaves like China, a nation of which no one is afraid of in ideological terms. There may be contradicting interests, but there is no struggle of ideologies. And, as Alla Kassianova writes, the West loses its importance as a reference point for Russia's self-definition, but there is no ideological pillar of an anti-Western foreign policy. ${ }^{85}$ Russia wishes to be recognized as a great power that has a role to play on the global stage. It is simply pursuing this aim with an approach that is better suited to its culture than those that would be dictated by Western norms.

82 Ibid., 72.

83 Jens Siegert, "Der Umgang mit Russland nach Kaukasus-Krieg und Finanzkrise," RusslandAnalysen 172 (31 December 2008): 13-15.

84

Samuel Huntington, "The Clash of Civilizations," Foreign Affairs 72:3 (Summer 1993): 45.

85 Alla Kassianova, "Russland - dem Westen gegenüber immer noch aufgeschlossen," Osteuropa 10 (2001): 1199-218. 


\section{Military Power Versus Economic Power}

In contrast to the role of the Red Army as the savior of the Bolshevik cause during the years 1916-22, the Soviet military did not intervene to save the Eastern Bloc at the end of the Cold War, and almost faded to insignificance in the following years. However, within the military and political elites, elements of the old strategic culture persisted.

Towards the end of Yeltsin's presidency, disappointment about Russia's position relative to the United States and the West took hold, and a broad consensus developed that a modernization of the military was needed. Due to the disastrous financial situation of the Russian state at the time, these reforms did not take place. ${ }^{86}$ At that time there was also a new way of thinking taking hold in the strongly militarized strategic culture of Russia. The importance of a functional economy for social welfare as well as for the exertion of power became apparent. The 1997 National Security Blueprint declared: "While military force factors retain their significance in international relations, economic [and] financial ... factors are playing an increasing role." The military organization was considered to be "burdensome to the state," and the goal of parity in military strength was no longer to be pursued. Rather, a "realistic deterrence" had come to be considered sufficient. This position was logical at the time, particularly as "the critical state of the economy" was considered to be "the main cause of the emergence of a threat to ... national security." ${ }^{\text {" }}$

Putin became even more precise in the Foreign Policy Concept of 2000. As Mankoff described the new approach, the pursuit of power means "seeking economic expansion and stability at home and using the benefits for strategic purposes." ${ }^{88}$ Putin expanded this conclusion, and used the then growing revenues of the state to pay back Russia's foreign debt ahead of time in order to reduce foreign leverage on Russia. ${ }^{89}$

In the Foreign Policy Concept of 2008, economic interdependence of states is even seen as becoming a key factor of international stability. ${ }^{90}$ In the wake of the Georgian war, Russia was taught a lesson in how deeply integrated markets are nowadays. Investors lost trust and withdrew their money from the Moscow stock exchange, investments were withheld, and Russian companies doing business in Europe reported problems with obtaining financing even before the international crisis reached Europe.

By 2000 at the latest one can assume that a fundamental shift had taken place in Russian strategic culture. The economy had come to be considered as an important pillar of Russian power, perhaps even more important than the military itself (with the exception of the nuclear deterrent, which in itself was considered an important pillar of

\footnotetext{
86 Ibid., 14.

87 Yeltsin, "Russian National Security Blueprint."

88 Mankoff, "Russia and the West: Taking the Longer View," 130.

89 Ibid

90 Medvedev, "Foreign Policy Concept."
} 
power enabling Russia to pursue great power status). ${ }^{91}$ The reason for this development may be twofold. First, the elites knew that it had been the economic weakness of the Soviet Union that finally had led to its collapse. The massive Soviet military build-up was simply not sustainable on such a shaky economic foundation. Second, Russia had experienced a severe financial crisis at the end of the 1990s, which had led to Russia's financial collapse.

Nevertheless, Russia increased its military spending constantly during Putin's presidency, and continues to do so under Medvedev. On average, there has been a rise of more than 20 percent a year ( 22 percent in $2006,{ }^{92} 16$ percent in $2008,{ }^{93} 27$ percent in $2009^{94}$ ). Even so, Russian defense spending amounts to less than 10 percent of that of the United States. ${ }^{95}$ Even if differences in purchasing power are accounted for, the discrepancy is more than obvious. Nevertheless, Putin claimed in his 2006 address to the Federal Assembly that "modernizing Russia's armed forces is extremely important today and is of [great] concern to Russian society," "96 even though he also stressed that there was no desire to enter into a new arms race: "Russia is not going to get involved in a costly confrontation, including renewed arms race, destructive for its economy and disastrous for its internal development." ${ }^{.97}$ Minister of Foreign Affairs Sergey Lavrov reiterated at a lecture that "raising living standards for all citizens of Russia is the highest priority of the Russian Government's policies." 98 This is a logical behavior, since nowadays the legitimacy of the governmental apparatus is earned through its performance, not by virtue of its ideology.

There are no intentions to return to Soviet superpower aspirations, despite resumption of flights with strategic bombers in 2007, despite naval visits to allies, etc. The military strategic value of these actions on the part of Russia is at best symbolic, and cannot be compared to the global presence of the Soviet Union. A successful comprehensive reform of the armed forces never took place. The war in Georgia proved the

91 "Finally, we need to make very clear that the key responsibility for ... ensuring global security will lie with the world's leading powers, the countries that possess nuclear weapons ...." Vladimir Putin, Annual Address to the Federal Assembly, 10 May 2006; available at www.kremlin.ru/eng/text/speeches/2006/05/10/1823_type70029type82912_105566.shtml. Valeria Korchagina, "Cabinet Set to Back Higher Spending," The MoscowTimes.com (18 August 2005); available at www.moscowtimes.ru/article/940/49/210513.htm.

93 "Russland erhöht Verteidigungsausgaben um 16\%," RIA Novosti (22 March 2007); available at http://de.rian.ru/safety/20070322/62459207.html.

94 "Russland steigert Militärausgaben um 25 Prozent," Welt Online (19 September 2008); available at http://www.welt.de/politik/article2467390/Russland-steigert-Militaerausgaben-um25-Prozent.html.

95 The United States spent USD 528.7 billion and Russia an estimated USD 34.7 billion (in 2005 dollars) on their military sectors in 2006 according to the SIPRI Annual Report (13 July 2007), cited at http://www.2020visioncampaign.org/es/pages/243/SIPRI_reports_on_World_ Nuclear_Forces_and_military_spending_2006.

97 Medvedev, "Foreign Policy Concept."

98 Lavrov, "Transcript of Remarks." 
huge discrepancy between Russian military capabilities and those of modern Western armed forces; $;{ }^{99}$ this war cannot in any terms be interpreted as the return of Russia as a global power. And even if there were further huge increases in defense spending over the next decade (which is not very likely due to the current financial crisis and the low oil and gas prices), the gap between Russian and U.S. spending would not decrease significantly. Russia is seemingly confined to being a regional power.

Other commentators who argue Russia should be contained are afraid of its emergent status as an energy superpower that can turn the flow of gas and oil to Europe on and off on will. But is Russia really able to exert pressure as an energy superpower? Russia is aware of the leverage provided by its huge gas and oil reserves, and it tries to strengthen the Kremlin's grip on the energy sector by exerting tighter control over gas and oil extraction as well as over the energy transport system. One can also observe that Russian companies are continuing to try to gain control of the downstream sector (processing and distribution). Russia together with OPEC controls more than 50 percent of today's world oil production. This share will even rise in the next twenty years. Russia therefore has the theoretical ability to cause severe disruptions for its consumers.

But there are also limitations on the use of energy as a weapon. To name just a few:

- If consumers feel too dependent, they start to increase their storage capacities, diversify their supply, and reduce consumption

- If energy is cut off, Russia will not be able to sell all of its gas somewhere else due to the heavy reliance on pipelines as a means of transport

- If the economies of the consumer nations are damaged as a result of being deprived of Russian natural resources, in an interdependent economic world, Russia's economy will also suffer over time.

Furthermore, Russia's economy is heavily dependent on foreign investment and functioning financial markets for its companies to refinance. Thus the use of energy as a weapon against the EU is contrary to the long-term interests of Russia, and is not likely to occur. Even during the latest quarrels with Ukraine about payments that caused severe disruptions in supply for large parts of Europe, it was in Russia's interest to pump as much gas as possible through pipelines that did not run through Ukraine. And Russia was also willing to accept a European monitoring team in order to be able to resume delivery via Ukraine. Russia does not want to lose the loyalty of its customers.

To sum up, we can see that there has been a significant change in Russia's strategic culture. The economy has become a critical power factor within Russian strategic thinking, and the result has been a civilizing influence on Russia's strategic culture. Despite increased defense spending, the Russian armed forces are not capable of exerting a global influence. Militarily, Russia has been reduced to a regional power that

99 Margarete Klein, "Militärische Implikationen des Georgienkrieges - Zustand und Reformbedarf der russischen Streitkräfte," SWP-Aktuell 74 (October 2008), 7. 
is going to maintain its nuclear deterrent at a high level, because this gives it more leverage on the international stage. Furthermore, the Russian leadership obviously seems to have accepted this regionally confined role. Energy is not likely to be used as a weapon against the West because of the likely repercussions on the Russian economy.

\section{Implications for the West}

Robert Kagan is right when he writes, "There is suspicion, growing hostility, and the well-grounded view on the part of the autocracies that the democracies, whatever they say, would welcome their overthrow." ${ }^{100}$ However, this thesis comes to a conclusion that actually contradicts what Kagan argues: "Complicating the equation ... is that the return to the international competition of ambitious nations has been accompanied by a return to global ideological competition." ${ }^{101}$ Russia currently has no expansionist ideology. Russia, as this article has pointed out, seeks the restoration of its status within a great power order, an improved standard of living for its people, and a clearly defined national identity. The way that Russia tried to pursue this tripartite goal in the postCold War era was strongly reactive to Western actions. As Roderic Lyne writes, "The war with Georgia is no exception, although many in the West believe it was a clever trap set for Mikheil Saakashvili." 102 This tit-for-tat policy has eroded the common basis of trust.

It is up to the West to ask the question: Which Russia do we want? Do we want to have a strong or a weak Russia? A Russia integrated into the international system, or one that is kept outside? Whatever action the West decides to take, it has to keep in mind that Russia - conforming to highly traditional modes of great power behaviorwill most likely react with counter-pressure and nationalistic rhetoric if cornered.

Bearing in mind that Russia, in accordance with the old system of a balance of power, still often adopts a zero-sum approach, the West should thereby avoid showing exploitable weaknesses while engaging this autocratic system. Russia still speaks a different "language" than post-modern Europeans do. As this essay has elaborated, Russian strategic culture has shifted toward a stronger emphasis on the economy, and it will most likely continue to follow this path. The modernization of Russia's economy - especially in the light of the international financial crisis-will not be possible in the foreseeable future without close cooperation and strong support from the West. Thus, like it or not, Russia is heavily dependent on the West. This eventually will bring about a greater Russian propensity toward utility maximization, and will open up the chance for new ways of cooperation in the future. Russia in the long run has more to gain from close cooperation than from driving a wedge between the Europeans or disrupting transatlantic relations. The West should try to assist this process by highlighting commonalities of interests, by reducing the points of friction, by alleviating Russian fears, and by channeling the interaction into a structured setting.

\footnotetext{
${ }^{100}$ Robert Kagan, "End of Dreams, Return of History," 10.

${ }^{101}$ Ibid., 7.

102 Lyne, "Reading Russia, Rewiring the West."
} 
Despite the gross imbalance of power between the two nations, the United States is still the reference point for Russia. Russia's historically reasoned longing for acceptance as a partner on equal terms determines its behavior. Thus, Vice President Biden's famous offer of an olive branch to Russia at the $45^{\text {th }}$ Munich Security Conference, where he claimed that "it is time to press the reset button and to revisit the many areas where we can and should work together," provides an opportunity for rapprochement. ${ }^{103}$ Most security issues cannot be solved by the U.S. alone. There are numerous realms of cooperation that should be addressed by the Obama Administration (e.g., arms control, the fight against pandemics, peaceful settlement of territorial claims in the Arctic, etc.). In order to open the way for fruitful discussions, the build-up of the U.S. missile defense shield in Poland and the Czech Republic had to be frozen (which took place in late 2009). Bearing in mind about the above discussion of Russia's strategic culture, the U.S. should not have unreasonably high expectations at the beginning of an engagement process. Confidence building will take time.

Europe's neighborhood is going to remain in an insecure transition phase for the next several years, as NATO enlargement as a method of expanding security has been shown to be no reasonable course after the events in Georgia. NATO enlargement to Georgia would arouse Russia's sense of being isolated and provoke it in terms of great power politics. In a far more severe consequence, it could also undermine the security guarantees that NATO has made to small countries in its sphere of influence. NATO membership is a deterrent to military action against a member state, "but only to the

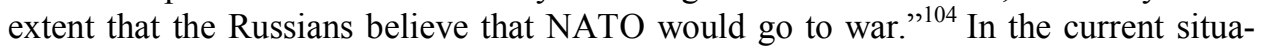
tion, if NATO membership were extended to Georgia, it may be perceived by Russia as a hollow security guarantee, and by extension the guarantees given to small countries like the Baltic States would come to be seen as non-credible as well. NATO enlargement would thus become destabilizing.

In order to increase the likelihood of a compromise among the Europeans about a rapprochement towards Russia, the Eastern European NATO members, whose paramount concern is still territorial integrity, have to be reassured of the Alliance's commitment to collective defense. The "Declaration on Alliance Security," which was adopted at the NATO $60^{\text {th }}$ Anniversary Summit in April 2009, as well as the British proposal to integrate an "Allied Solidarity Force" within the NATO Response Force, are positive signals in this direction. To position more troops in the Eastern European member states or to build a NATO missile defense system would rather be steps that would provoke a negative response, given Russia's strategic culture.

At the same time, the EU cannot afford to live in a constant state of strategic uncertainty, much less have an open conflict with Russia, for three main reasons: its lack of military strength, which keeps it dependent on U.S. security guarantees; its dependence on Russian energy supplies; and its economic interests, which would be hurt in case of crisis by the repercussions from the global markets and its interdependency

${ }^{103}$ Joseph R. Biden, Speech at the $45^{\text {th }}$ Munich Security Conference, 7 February 2009; available at www.securityconference.de/Joseph-R-Biden.234.0.html.

${ }^{104}$ Lyne, "Reading Russia, Rewiring the West." 
with Russia. Furthermore, those countries that are not comfortably within EU and NATO that serve as a buffer zone between the two blocs would constantly be victims of a struggle for predominance, and in some cases might be torn apart.

The deepening of EU integration - especially in its Common Foreign and Security Policy - and the further build-up of military capabilities within the European Security and Defense Policy process will lead to the emergence of an EU that may be seen as a unified bloc, with Russia isolated on the outside, looking in. The present implication of this is the need to identify realms in which structural cooperation with Russia could be achieved on basis of common goals (e.g., avoidance of an arms race and proliferation of weapons of mass destruction, counterterrorism efforts, cooperation in dealing with the global financial crisis, assistance in the transformation of the Russian economy, climate change) and areas where there may be areas of disagreement that may be unlikely to be resolved if neither side is willing to compromise (such as the active promotion of Western values within Russia). Confrontational issues, which play into the hands of traditional great power politics, should be handled very carefully. Any step that is likely to be perceived in Russia as tending toward containment or humiliation, even if the perception is due to miscommunication or mistrust, will most likely lead to more aggressiveness. In turn, the effectiveness of EU soft power will be reduced, and a call for U.S. assistance will become more likely.

The EU, whether it likes it or not, has to accept that Russia is part of Europe. As such, in the long run Russia has to be integrated into a new comprehensive security architecture and a close economic partnership on equal terms, with neither side being allowed a veto over each others' issues. Most likely the type of "architecture" that has to be developed will be fundamentally different from the non-flexible institutional types of security architecture that are currently in use. It presumably will include functional differentiations and a variable geometry. It may be closer to some form of networked diplomacy within foreign policy, which "is only one part of a broader 'global engagement' between societies." Overall, networks are considered to be "ultimately self-optimizing," and "the more appropriate people they connect, the more useful and attractive the network becomes to others." 105 The necessary framework should have a strong commitment to the rule of law. Russia should be challenged on its pledges to multilateralism, because a multipolar world without multilateralism is most prone to conflict.

Keeping Russia locked out of the European house does not solve any problems, since it will still be sitting on the doorstep. Thus, giving serious attention to Medvedev's open proposal of restructuring the European security architecture in a discursive approach similar to the one taken in Helsinki in the mid 1970s may be the next step to take, bearing in mind the faults of the OSCE and Russia's tendency to pursue its own interests. Mutual understanding and trust will grow, and necessary changes on the internal levels of both actors may slowly take place, often having their roots deep in his-

105 Jamie Metzl, "Network Diplomacy," Georgetown Journal of International Affairs (Winter/Spring 2001); available at http://www.carnegieendowment.org/publications/index.cfm? $\mathrm{fa}=$ view\&id $=681$. 
torical experiences. The EU should not cross the line of making concessions that would manifest a sphere of special or even exclusive interest for either side. Spheres of interest will only lead to a cementation of bloc-centered approaches to foreign and security policy.

Speaking in terms of realpolitik, this rapprochement will be of mutual benefit. On the one hand, Russia has no natural allies, as the differences between Russia and China are even bigger than the differences between Russia and the EU. On the other hand, in terms of relative power the EU is constantly losing ground in comparison to the U.S. and China. Furthermore, the EU-a great power itself - has to bear in mind that it has its own interests to pursue apart from the U.S., and thus should avoid being a mere element that is balanced by the U.S. against Russia. By embracing each other more as partners, a tamed Russia and a strengthened EU could become one of the future power blocs. Strategic engagement with Russia implies strategic risks, but it may eventually bring about strategic gains. Non-engagement will perpetuate the current strategic instability, and will most likely lead to underperformance on the part of both actors.

\section{Conclusions}

A unique strategic culture evolved out of Russia's history and geography that still strongly influences Russia's foreign and security policy. This strategic culture is characterized on one hand by an almost obsessive perception of a general threat towards Russian sovereignty and territorial integrity, and on the other hand by great power aspirations as a response. Only autocratic leadership is seen to be able to cope with the challenges to which Russia is exposed. Without understanding Russia's strategic culture, decision makers in the West will not be able to make adequate policy choices. It is important for Western policymakers to be aware of Russia's longer historical legacy, not just that of the Soviet era. Russia's strategic culture seems to be fairly stable at present; the new vector opened by the collapse of the Soviet Union could not persist in all its dimensions against the dominating culture, although in some realms significant changes occurred.

Imperial Russia from its very beginning had one of the most militarized cultures in history. In the years after the collapse of the Soviet Union, the opportunity arose to demilitarize Russian culture. ${ }^{106}$ And it actually happened. The humiliating defeat in Afghanistan, the unbearable burdens of an arms race with the West, the cost of the war in Chechnya all led to one conclusion: no more large-scale arms race. One remaining relic of this earlier era is the reliance on nuclear strategic forces as main deterrent in order to protect the Russian heartland.

Economic factors have come to play an ever more important role as a source of power for Russia. A rebalancing of the needs of the Russian population against the cost of great power status took place, but the rise in the nation's economic power due to the sharp increase in oil and gas revenues from 2006-08 led to a change in relative power. The rise in tensions between the West and Russia can be attributed to this changed

${ }^{106}$ Ermarth, "Russian Strategic Culture," 3. 
power equation, rather than to a newly aggressive stance on Russia's part. The sharp drop of oil revenues and Russia's increased dependence on international financial markets may temper its tone again. In addition, Russia's lack of any expansionistic ideology and global power aspirations is also notable. Moscow's long-term strategy is not to challenge the West fundamentally, but it wants to be involved as a great power in decision making on the international stage.

Even though Russia emphasizes the role of multinational institutions (especially of the United Nations) "as a clearing-house for the coordination of international relations and world politics in the twenty-first century,"107 it prefers to act on the level of other great powers, rather than through international institutions. As a great power, Russia also claims the right to exercise privileged interests in certain regions (namely the CISregion). This claim is likely the most controversial element of Russia's current foreign policy stance, and can make compromise all the more difficult. The underlying feature of these distortions is the still prevailing Cold War-era mindset of two monolithic opposed blocs that is leading to continued strategic instability within Europe, which also has a ripple effect on other global issues.

However, Russia's real power, and thus the threat posed to the West, is often exaggerated. Russia's sustainable military power at its best has a regional dimension. Its nuclear weapons can plausibly only be used defensively, its economy still has to undergo a long transition, the use of energy as a weapon would have negative repercussions on Russia, and its veto power on the UN Security Council may be circumvented by unilateral action on the part of the United States.

In line with its strategic culture, Russia believes it would achieve greater gains in its quest for renewed great power status if it adopted a tough stance toward the U.S. To attenuate these tensions, the West should therefore react assertively but moderately to heated Russian rhetoric and other provocations, and should engage in constructive cooperation on non-classical security threats and economic issues, including close cooperation to mitigate the effects of the international financial crisis on Russia. Starting in 2009, the West should work with Russia to develop a new concept for long-term security. Future research should thus focus on forward-looking networked diplomacy approaches that may be suited to overcome the lingering effects of the Cold War mentality.

${ }^{107}$ Medvedev, "Foreign Policy Concept." 


\section{Bibliography}

Adams, Karen. "Great Power: What Will It Take?" In conference of the International Studies Association. Montreal, 2004.

Almond, Gabriel, and Sidney Verba. The Civic Culture: Political Attitudes and Democracy in Five Nations. Boston: Little Brown, 1965.

Bailes, Alyson. New European Security Treaty Worth Trying. Utrikesbloggen, 2009.

Biden, Joseph R.. Speech at the 45th Munich Security Conference., 2009.

Bogaturov, Aleksei D., and Tatyana A. Shakleyyina. "The Russian Realist School of International Relations." Communist and Post-Communist Studies 37, no. 1 (2004): 37.

Bremmer, Ian, and Samuel Charap. "The Siloviki in Putin's Russia." The Washington Quarterly 84 (2007).

Carpenter, Ted Galen. "What Russia Wants." The American Conservative (2008).

Cohen, Ariel. Domestic Factors Driving Russia’s Foreign Policy In Backgrounder. The Heritage Foundation, 2007.

de Haas, Marcel. "Russia's Upcoming Revised Military Doctrine." Power and Interest News Report (2007).

Dubin, Boris. "Fernsehkrieg und echter Krieg - Russland: Der Kaukasus-Konflikt in den Köpfen." Osteuropa (Berlin) 11 (2008): 72.

Duffield, John S.. World Power Forsaken: Political Culture, International Institutions, and German Security Policy after Unification. Stanford, CA: Stanford University Press, 1999.

Ermarth, Fritz W.. Russian Strategic Culture: Past, Present, and... in Transition?. Advanced Systems and Concepts Office of the Defense Threat Reduction Agency, 2006.

Goshko, John M.. "Yeltsin Claims Russian Sphere of Influence." The Washington Post (1994).

Gray, Colin S.. The Geopolitics of Superpower. Lexington: University of Kentucky Press, 1988.

Gvosdev, Nikolas. 'Because It Is': Russia, The Existential Great Power. The National Interest, 2006.

Heikka, Henrikki. Strategic Culture and the English School In Working Papers. Oslo: Finish Institute of International Affairs, 2002.

Herz, John H.. "Political Realism and Political Idealism." American Sociological Review 16 (1951): 733-34.

Huntington, Samuel. "The Clash of Civilization." Foreign Affairs 72, no. 3 (1993). 
Ivanov, I.S.. "The Foreign Policy Concept of the Russian Federation." In The New Russian Diplomacy. Washington, D.C.: The Nixon Center and Brookings Institution Press, 2002.

Ivanov, I.S.. "The Foreign Policy Concept of the Russian Federation." In The New Russian Diplomacy. Washington, D.C.: The Nixon Center and Brookings Institution Press, 2002.

Johnston, Alistair Iain. "Thinking about Strategic Culture." International Security 19, no. 4 (1995): 37-39.

Johnston, Alistair Iain. Cultural Realism, Strategic Culture and Grand Strategy in Chinese History. Princeton, NJ: Princeton University Press, 1995.

Kagan, Robert. "End of Dreams, Return of History." Policy Review 143 (2007): 5.

Kagarlitsky, Boris. Russia Under Yeltsin and Putin: Neo-Liberal Autocracy. London: Pluto Press, 2002.

Kassianova, Alla. "Russland - dem Westen gegenüber immer noch aufgeschlossen." Osteuropa 10 (2001): 1199-218.

Kazantsev, Andrei. "Russian Policy in Central Asia and the Caspian Sea Region." Europe-Asia Studies 60, no. 6 (2008): 1073-1088.

Kennan, George F.. "The Sources of Soviet Conduct." Foreign Affairs (1947).

Klein, Margarete. "Militärische Implikationen des Georgienkrieges - Zustand und Reformbe-darf der russischen Streitkräfte." SWP-Aktuell 74 (2008): 7.

Korchagina, Valeria. Cabinet Set to Back Higher Spending. The MoscowTimes.com, 2005.

Kortunov, Sergei. Should Russia Claim Great Power Status. RIA Novosti, 2006.

Lavrov, Sergei. Speaking Notes at the Los Angeles World Affairs Council., 2006.

Lavrov, Sergei. Transcript of Remarks by Russian Minister of Foreign Affairs at the Myrdal Lecture. Geneva, 2008.

Lomanov, Alexander. "Transition Without a Destination." Russia in Global Affairs 6, no. 2 (2008): 20-34.

Lyne, Roderic. Reading Russia, Rewiring the West. opendemocracy.net, 2008.

Mackinder, Halford J.. "The Geographical Pivot of History." The Geographical Journal (1904): 421-37.

Mankoff, Jeffrey. "Russia and the West: Taking the Longer View." The Washington Quarterly (2007): 128. 
Mansfield, Edward D., and Jack Snyder. Electing to Fight: Why Emerging Democracies Go to War. Cambridge, MA: MIT Press, 2005.

Medvedev, Dmitry. Russia Won’t Accept Unipolar World., 2008.

Medvedev, Dmitry. Speech at Meeting with German Political, Parliamentary, and Civic Leaders. Berlin, 2008.

Metzl, Jamie. "Network Diplomacy." Georgetown Journal of International Affairs (2001).

Monaghan, Andrew. Russia Will Propose a new Foreign Policy Concept to NATO In Immediate Report. Rome: NATO Defense College, 2008.

National Security Concept of the Russian Federation. Rossiiskaya Gazeta (2000).

Neumann, Iver B.. "When Did Russia Become a Great Power? Realist, Constructivist and Post-Structuralist Answers." In conference of the International Studies Association. Chicago, 2007.

Nicholl, Helen R., and Nicholas J. Spykman. The Geography of the Peace. New York.: Harcourt, Brace, and Co, 1944.

Pivovarov, Jurij. Politieskaja istorija Rossii. Berlin: SWP-Zeitschriftenschau, 2003.

Póti, László. "Evolving Russian Foreign and Security Policy: Interpreting the Putindoctrine." Acta Slavica Iaponica 25 (2008): 41.

Primakov, Yevgeny. "Turning Back Over the Atlantic." International Affairs: A Russian Journal of World Politics 6 (2002): 69.

Putin, Vladimir. Annual Address to the Federal Assembly., 2007.

Russland erhöht Verteidigungsausgaben um 16\%. RIA Novosti, 2007.

Russland steigert Militärausgaben um 25 Prozent. Welt Online, 2008.

Saakashvili, Mikheil. "Moscow's Plan Is to Redraw the Map of Europe." Financial Times (2008).

Scheffer, Jaap de Hoop. Speech at the 43rd Munich Conference on Security Policy., 2007.

Sevcova, Lilija. "Ende einer Epoche—Russlands Bruch mit dem Westen." Osteuropa (Berlin) 11 (2008): 65-68.

Siegert, Jens. "Der Umgang mit Russland nach Kaukasus-Krieg und Finanzkrise." Russland-Analysen 172 (2008): 13-15.

Snyder, Jack. The Soviet Strategic Culture: Implications for Nuclear Options. Santa Monica, CA: RAND Corporation, 1977. 
Terry, Bruce W.. "European Balance of Power: Will the European Union Upset Russia as it Balances the United States?" In Conference of the International Studies Association. San Diego, CA, 2006.

Van Herpen, Marcel H.. Medvedev's Proposal for a Pan-European Security Pact In Cicero Working Paper. Paris/Maastricht, 2008.

Yasmann, Victor. Russia: Moscow's New Nuclear Strategy. Radio Free Europe/Radio Liberty, 2006.

Yeltsin, Boris. "Russian National Security Blueprint." Rossiiskaya Gazeta (1997). 